\title{
A Review on Medicinal Constituents and Therapeutic Potential of Moringa oleifera
}

\author{
Mitali Srivastava, Prashant K Dhakad*, Birendra Srivastava \\ School of Pharmaceutical Sciences, Jaipur National University, Jaipur, Rajasthan, India \\ Received December 28, 2019; Revised March 2, 2020; Accepted March 12, 2020
}

Copyright $\odot 2020$ by authors, all rights reserved. Authors agree that this article remains permanently open access under the terms of the Creative Commons Attribution License 4.0 International License

\begin{abstract}
Moringa oleifera is an old plant known for its different restorative properties referenced in Ayurveda. It has a place with the Moringaceae family. It is ordinarily named as Sainjana in Hindi and Drumstick or Horseradish tree in English. It belongs to tropical and subtropical regions. It is found in India, Philippines, South Asia, Indonesia, Central America, Africa, and Caribbean. Generally, Moringa oleifera has been utilized or its different restorative properties, for example, as wound healing, anti-diabetic, pain relief, anti-inflammatory, cancer prevention. All aspects of this plant contain a significant therapeutic component. Numerous basic supplements have been found in Moringa oleifera for example nutrients, minerals, amino acids, omega 3 and 6 unsaturated fats, antioxidants and $\beta$-carotene. It is a high wellspring of nutrients and minerals, leaves and pods contain bottomless measure of manganese, different minerals, for example, $\mathrm{K}, \mathrm{Cu}, \mathrm{Na}, \mathrm{Mg}, \mathrm{Fe}, \mathrm{Zn}, \mathrm{Cl}, \mathrm{P}$, and so forth are additionally present in Moringa oleifera. Different parts of Moringa oleifera possess a great wellspring of glucosinolates, flavonoids, phenolic compounds, polyunsaturated fatty acids, monounsaturated fatty acids and others. Different definitions are accessible in the market of Moringa oleifera, for example, seed oil, dried leaves powder, paste, tablet are accessible there for different uses. The present review focuses on the biological sources, phytoconstituents, toxicological studies, multipurpose uses and possible pharmacological activities carried out on Moringa oleifera.
\end{abstract}

Keywords Moringa oleifera, Pharmacological Activities, Phytoconstituents, Industrial Uses, Drumstick

\section{Introduction}

Plants are significant for the treatment of the ailments. In Ayurveda, different plants are referenced for their distinctive therapeutic properties, for example, pain relief, calming, antipyretic, hostile to diabetic and so forth. Moringa oleifera is one of such plants utilized due its different therapeutic properties; for example, wound healing, anti-diabetic, pain relieving, cell reinforcements. Moringa oleifera is health restorative plant and it is very well-known in tropical and subtropical nations. Generally, Moringa oleifera is being utilized for its anti-inflammatory property because of its constituents found in leaves. In India, poultices of seed units have been utilized to treat glandular aggravation. Different investigations on extracts of Moringa oleifera seed pods, leaves, seeds done on human subjects, and animals as well as toxicity studies examined so far recommends that they are protected to use in normally used portions. Moringa oleifera shows pharmacological properties like anti-asthmatic, hepato-defensive, anti-fertility, anticancer, antimicrobial, cardiovascular, against ulcer, antipyretic action [1].

Scientific Classification

Kingdom - Plantae

Sub kingdom - Tracheobionta

Super division - Spermatophyta

Division - Magnoliophyta

Class - Magnoliopsida

Sub class - Dilleniidae

Order - Capparales

Family - Moringaceae

Genus - Moringa

Species - oleifera

\subsection{Botanical Description}

The development of Moringa oleifera in India is found in the most part in the southern conditions of Tamil Nadu, Kerala, Andhra Pradesh and Karnataka. India is the biggest maker of Moringa oleifera, with a yearly creation of 1.2 million tones of organic products from a territory of Three hundred and eighty $\mathrm{km}^{2}$. Moringa oleifera is developed in home nurseries and as living wall in South 
Asia and Southeast Asia, where it is generally sold in neighborhood markets. In the Indonesia, it is regularly developed for its leaves which are utilized as nourishment. Moringa oleifera is likewise effectively developed by the World Vegetable Center in Taiwan, for vegetable research purpose. Moringa oleifera is an evergreen or deciduous tree which typically grows up to 10 to $12 \mathrm{~m}$ in tallness. Leaves are bipinnate or tripinnate fluffy, green leaves and the leaflets are upto $1-2 \mathrm{~cm}$. The leaflets are bristly and practically bald on the upper surface while the twigs are furry and green. Blossoms are typically white in shading with furry stalks and individual bloom is upto $1 \mathrm{~cm}$ long and $2 \mathrm{~cm}$ wide. They are indiscriminate, fragrant and with hanging auxillary of 10 to $25 \mathrm{~cm}$ long. The 5 sepals are direct lanceolate type while 5 petals are thin spatulate. They encompass the 5 stamens and 5 staminodes and are reflexed aside from the least. Natural products are frequently referred as pods. They are tri-lobed cases; youthful units are green in shading. The develop pods are dark colored triangular, pendulous, and split into three sections the long way when dry 30 to $120 \mathrm{~cm}$ long, $1.8 \mathrm{~cm}$ wide natural products generation for the most part happens in March and April. Fruits possess around 26 seeds during their advancement organize. Seeds are round and caramel in shading with $1 \mathrm{~cm}$ in distance across. It has a semi-penetrable seed frame with 3 papery wings bodies. Seeds are dark colored however can be white if portions are of low suitability. Reasonable seed develop inside about fourteen days; each tree can deliver around 15,000 to $25,000 \mathrm{seeds} / \mathrm{year}$. Normal weight is $0.3 \mathrm{gm}$ per seed [2-4].

\section{Phytochemistry}

Numerous basic supplements have been found in Moringa oleifera for example nutrients, minerals, amino acids, $\beta$-carotene, omega 3 and 6 unsaturated fats and cell reinforcements. It is a high wellspring of nutrients and minerals, leaves and pods contain rich measure of different minerals. Moringa oleifera leaves are accepted as wellspring of nutrient such as carbon, chloride, potassium, beta carotene just as protein. Different parts of Moringa oleifera has been considered as great source of glucosinolates, phenolic acids, and flavonoids. 4-O-(a-L-rhamnopyranosyloxy)-benzylglucosinolate, one of the glucosinolates, is transcendently found in flowers, roots, stem, leaves, pods, and seeds. High content of glucosionlates are found in leaves and seeds. Glucosinolates is one of the significant parts in Moringa oleifera tree. It is catabolised enzymatically by plant's compound myrosinase into thiocarbamates, nitriles, isothiocyanates which are known for their solid hypertensive and spasmolytic impacts. Moringa oleifera have high substance of fiber in it and it is generally excellent from stomach related perspective. It contains isothiocyanates which wipes out H.pylori from the gut and is utilized in the significant sicknesses like gastritis ulcer and gastric malignancy. The Moringa oleifera leaves are high wellspring of omega 3 and omega 6 polyunsaturated unsaturated fats. It is elusive a plant having so a lot of gainful characteristics in its each part whether it be leaves, blooms, pods, seeds and so forth. Some chemical constituents are expressed in Table 1 [5-7].

\section{Pharmacological Activities}

In Ayurveda, Moringa has been mentioned as the tree of god for its multiple uses to treat various diseases. From ancient times different parts of Moringa oleifera has been used to treat epilepsy, chronic rheumatism, dropsy, dyspepsia, fever, etc. Moringa oleifera possess vast pharmacological activities. Some of them are summoned in Table 2.

Table 1. The major phyto-constituents found in different parts of Moringa are given below

\begin{tabular}{|l|l|c|}
\hline PART OF PLANT & CHEMICAL CONSTITIUENTS & REFERENCES \\
\hline Leaves & $\begin{array}{l}\text { 4-O-(a-L-rhamnopyranosyloxy)-benzylglucosinolate, quercetin, kaempferol, carotenoids, } \\
\alpha \text {-tocopherol, a-linolenic acid, linoleic acid, Palmitic acid, Ca, Fe, Niaziminin A, and } \\
\text { Niaziminin B, three mustard oil glycosides, niaziminin, a thiocarbamate,4(alpha-1- } \\
\text { rhamnopyranosyloxy)-benzylglucosinolate, quercetin-3O-glucoside and quercetin-3-O-(6'- } \\
\text { Malonyl-glucoside), Niazimicin. }\end{array}$ \\
\hline Flowers & $\begin{array}{l}\text { Monounsaturated fatty acids (MUFAs), ascorbic acid, protein, D-mannose, kaemopherol, } \\
\text { kaempferitin }\end{array}$ & [1] \\
\hline Fruit / Seed Pods & $\begin{array}{l}\text { Carotenoids, monounsaturated fatty acids } \\
\text { O-ethyl-4-(alpha-L-rhamnosyloxy) benzyl carbamate, methyl- p-hydroxybenzoate, beta- } \\
\text { sitosterol }\end{array}$ & [8] \\
\hline Roots & $\begin{array}{l}\text { Benzyl glucosinolate (glucotropaeolin), Moringine, moringinine, spirachin, 1,3-dibenzyl } \\
\text { urea, alpha- phellandrene, p-cymene, Deoxy-niazimicine. }\end{array}$ & [6] \\
\hline Seeds & $\begin{array}{l}\text { Oleic acid, palmitoleic acid, stearic acid, arachidic acid, Dodecanoic acid, tetradecanoic acid, } \\
\text { hexadecanoic acid, octadecanoic }\end{array}$ & [7] \\
\hline Stem & $\begin{array}{l}\text { Glucomoringin, } \beta \text { - sitosterone and } \beta \text { - sitosterol. } \\
\text { [6] }\end{array}$ \\
\hline
\end{tabular}




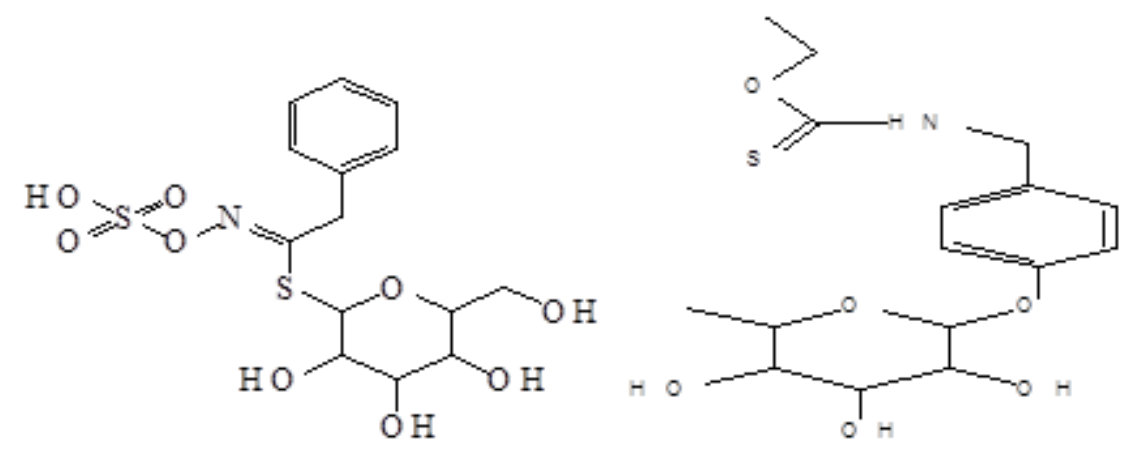

(a)

(b)<smiles>CC(=O)OC1C(C)OC(Oc2ccc(CN=C=S)cc2)C(O)C1O</smiles>

(c)

(d)<smiles>O=c1c(O)c(-c2ccc(O)c(O)c2)oc2cc(O)cc(O)c12</smiles>

(e)<smiles>O=c1c(O)c(-c2ccc(O)cc2)oc2cc(O)cc(O)c12</smiles>

(f)<smiles>CCCCC/C=C/C/C=C\CCCCCCCC(=O)O</smiles>

$(\mathrm{g})$

(h) 
<smiles>O=c1c(OC2O[C@H](O)[C@H](O)[C@H](O)[C@H]2O)c(-c2ccc(O)c(O)c2)oc2cc(O)cc(O)c12</smiles>

(i)<smiles>CC1OC2OCC3C(O)C(O)C(O)C(O)C3OC(Oc3c(-c4ccc(O)c(O)c4)oc4cc(O)cc(O)c4c3=O)C(O)C1O2</smiles>

(k)<smiles>CCOC(=O)NCc1ccc(OC2OC(C)C(O)C(O)C2O)cc1</smiles>

(j)<smiles>C[C@@H]1O[C@H](Oc2ccc(CC/C(=N/OS(=O)(=O)O)S[C@@H]3OC(O)[C@H](O)[C@@H](O)[C@H]3O)cc2)[C@H](O)[C@@H](O)[C@H]1O</smiles>

(1)<smiles>Cc1c(O)c(O)c(C)c2c1CCC(C)(CCCC(C)CCCC(C)CCCC(C)C)O2</smiles>

(m)

(n)

Figure 1(a-n). (a) Benzyl glucosinate, (b) Niazimicin, (c) 4-(4'-O-acetyl-a-L-rhamnosyloxy) benzyl isothiocyanate, (d) Benzyl-isothiocyanate, (e) Kaemopherol, (f) Quercetin, (g) $\beta$-sitosterol, (h) Linoleic acid, (i) Quercetin-3-o-glucoside, (j) O-ethyl-4-(alpha-L-rhamnosyloxy) benzyl carbamate, (k) Rutin, (l) Glucomoringin, (m) $\alpha$-tocopherol, (n) Ascorbic acid. 
Table 2. Representation of various pharmacological activities found in different parts of Moringa oleifera plant is described below.

\begin{tabular}{|c|c|c|c|c|c|}
\hline Plant parts & $\begin{array}{l}\text { Pharmacological } \\
\text { activity }\end{array}$ & \multicolumn{2}{|c|}{ Findings/Outcomes } & $\begin{array}{l}\text { Possible } \\
\text { phytoconstituents }\end{array}$ & References \\
\hline $\begin{array}{l}\text { 1. Moringa } \\
\text { oleifera leaves }\end{array}$ & Anti-diabetic activity & $\begin{array}{l}\text { a) } \\
\text { b) } \\
\text { c) } \\
\text { d) } \\
\text { e) } \\
\text { f) } \\
\text { g) }\end{array}$ & $\begin{array}{l}\text { Ethanol extract of Moringa oleifera leaves reduces blood glucose level, } \mathrm{HbAlc} \text { and glycogen level. } \\
\text { Ethyl acetate fraction of Moringa reversed the symptoms shown by STZ such as loss of body weight, increase } \\
\text { in average water and food consumption. } \\
\text { Aqueous extract of Moringa oleifera leaves possess dose-dependent hypoglycemic activity in normoglvcemic } \\
\text { and hyperglycemic animals. } \\
\text { Aqueous leaf extract reduced albumin serum levels and total protein indicates the reduction of blood glucose } \\
\text { level in diabetes treated group. } \\
\text { Aqueous extract of leaves reduces the blood glucose level in normal rats and normalizes the level in mild, sub } \\
\text { and severe diabetic rats. } \\
\text { Ethanol extract of leaves reduced blood glucose level in pretreated group. As well as it decreased } \\
\text { dose-dependently, blood glucose level in the period of } 14 \text { days. In normal rats, decline of blood glucose level } \\
\text { has been found gradually. } \\
\text { Aqueous extract of Moringa oleifera leaves was analyzed to study its effect for wound healing in STZ-induced } \\
\text { diabetic rats. The study shown that the extract influenced the healing of the skin wounds after systemic and } \\
\text { topical treatment. }\end{array}$ & $\begin{array}{l}\text { Terpenoids, quercetin, } \\
\text { chlorogenic acid, } \\
\text { kaempferol, flavanoids, } \\
\text { proteins, fixed oils and } \\
\text { fats and carbohydrates }\end{array}$ & $\begin{array}{l}{[8]} \\
{[9]} \\
{[10]} \\
{[11]} \\
{[12]} \\
{[13]} \\
{[14]}\end{array}$ \\
\hline $\begin{array}{l}\text { 2. Moringa } \\
\text { oleifera leaves }\end{array}$ & Anti-convulsant activity & & $\begin{array}{l}\text { The study showed that hexane and ethanol extracts of Moringa leaves produced delay in seizures latency. } \\
\text { Moringa leaves possess anticonvulsant properties due to the complementary of the non-polar and polar } \\
\text { constituents. }\end{array}$ & Linoleic acid & {$[15]$} \\
\hline $\begin{array}{l}\text { 3. Moringa } \\
\text { oleifera leaves }\end{array}$ & Anti-depressant activity & a) & $\begin{array}{l}\text { Alcoholic extract of Moringa leaves were evaluated for antidepressant activity by three animal models, forced } \\
\text { swim test, tail suspension test and locomotor activity test. It was concluded that it possess antidepressant } \\
\text { activity. } \\
\text { Ethanolic extract of Moringa leaves were prepared to evaluate neurobehavioral properties by using open field, } \\
\text { hole board, Y-maze, elevated plus maze and pento -barbitone induced hypnosis. The findings from this study } \\
\text { suggested that the extract of MO leaves possess CNS depressant and anticonvulsant activites which possibly } \\
\text { be mediated through enhancement of central inhibitory mechanism involving release of GABA. }\end{array}$ & $\begin{array}{l}\text { Quercetin, kaempferol, } \\
\text { glucosinolates, fatty } \\
\text { acids, isothiocyanates, } \\
\text { hexadecanoic acid, } \\
\text { flavonoids and phenols. }\end{array}$ & $\begin{array}{l}{[16]} \\
{[17]}\end{array}$ \\
\hline $\begin{array}{l}\text { 4. Moringa } \\
\text { oleifera leaves }\end{array}$ & $\begin{array}{l}\text { Anti-inflammatory } \\
\text { activity }\end{array}$ & & $\begin{array}{l}\text { Dried and milled Moringa oleifera leaves were extracted with ethanol/water }(4: 1) \text { followed by a series of } \\
\text { liquid-liquid extractions. From the study it was concluded that, the extracts prepared using polar solvents had } \\
\text { significantly higher antioxidant capacities. } \\
\text { Moringa oleifera leaf extracts were tested for its antioxidant activity by two stages of maturity using standard } \\
\text { in vitro models. It was concluded that Moringa oleifera leaves possess potent antioxidant activity. From the } \\
\text { analysis it was revealed that there were minor differences in the antioxidant activity in the mature and tender } \\
\text { leaves. } \\
\text { Ethanol extracts of Moringa leaves against experimentally diclofenac sodium induced liver toxicity in male } \\
\text { rats. HPLC was performed for indentifying phenolic compounds. From the results it was concluded that } \\
\text { administration of extract improved liver and kidney functions. It has a beneficial effect against oxidative }\end{array}$ & $\begin{array}{l}\text { Glucosinolates, } \\
\text { isothiocyanates, } \\
\beta \text {-carotene, } \alpha \text {-tocopherol, } \\
\text { vanillin, benzoic acid, } \\
\text { salicylic acid, } \\
\text { chlorogenic acid, } 3,4,5- \\
\text { methoxy - cinnamic } \\
\text { acid. }\end{array}$ & $\begin{array}{l}{[18]} \\
{[19]} \\
{[20]} \\
{[21]}\end{array}$ \\
\hline
\end{tabular}




\begin{tabular}{|c|c|c|c|c|c|}
\hline & & d) & $\begin{array}{l}\text { liver damage induced by DcNa. } \\
\text { Moringa oleifera leaves extracted with methanol and dichloromethane were screened for antioxidant activity. } \\
\text { Radical scavenging assays with 1, 1-diphenyl-2-picrylhydrazyl (DPPH) and } 2,2^{\prime} \text {-azino-bis } \\
\text { 3ethylbenzothiazoline-6-sulfonic acid (ABTS) were used to determine the antioxidant activity. The study } \\
\text { provides evidence that M. oleifera leaves possess antioxidant activity. }\end{array}$ & & \\
\hline $\begin{array}{l}\text { 5. Moringa } \\
\text { oleifera leaves }\end{array}$ & Anti-oxidant activity & b) & $\begin{array}{l}\text { Aqueous and ethanol extracts were prepared from leaves of Moringa. During the test, suppression in oedema } \\
\text { was observed which may be due to the inhibitory effects on the release of histamine, } 5 \text {-ydroxy tryptamine and } \\
\text { kinin like substances which are reported to release from mast cell degradation during first hour of carrageen } \\
\text { induced artificial paw oedema. } \\
\text { Dried matured leaves were extracted with hexane and ethanol. The study gives the evidence of the broad } \\
\text { spectrum of anti-inflammatory activities in the use of Moringa oleifera leaves polar extracts. } \\
\text { Methanol extract of Moringa leaves was evaluated for anti-inflammatory effects by carrageen - induced paw } \\
\text { oedema test and histamine-induced pedal oedema test. From the results, it was concluded that the methanol } \\
\text { extract of Moringa oleifera leaf possesses a significant anti-oedematogenic effect on paw oedema induced by } \\
\text { carrageen and histamine. }\end{array}$ & 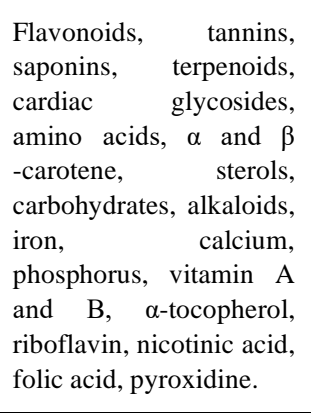 & $\begin{array}{l}{[22]} \\
{[23]} \\
{[24]}\end{array}$ \\
\hline $\begin{array}{l}\text { 6. Moringa } \\
\text { oleifera leaves }\end{array}$ & Anticancer activity & a) & $\begin{array}{l}\text { Moringa oleifera leaves were extracted by methanol and dichloromethane. The extract was investigated for its } \\
\text { chemoprotective and antiproliferative activity. From the study it was concluded that, it possess antioxidant } \\
\text { activity, as well as cytotoxic and chemoprotective properties. }\end{array}$ & $\begin{array}{l}\text { Polyphenol, gallic acid, } \\
\text { quercetin } \begin{array}{r}\text { and } \\
\text { kaempferol, glycosides, } \\
\text { flavonoids }\end{array}\end{array}$ & [21] \\
\hline $\begin{array}{l}\text { 7. Moringa } \\
\text { oleifera leaves }\end{array}$ & $\begin{array}{l}\text { Anti hyper-lipedemic } \\
\text { activity }\end{array}$ & a) & $\begin{array}{l}\text { Hydroalcoholic extract was prepared from Moringa leaves. From the study it was concluded that the sitosterol } \\
\text { inhibit the absorption of dietary cholesterol. }\end{array}$ & $\begin{array}{l}\beta \text {-sitosterol, flavonoids, } \\
\text { polyphenols. }\end{array}$ & [25] \\
\hline $\begin{array}{l}\text { 8. Moringa } \\
\text { oleifera } \text { stem }\end{array}$ & Anti-cancer activity & a) & $\begin{array}{l}\text { AgNPs of shade dried Moringa oleifera stem bark were prepared. These nanoparticles showed dose-dependent } \\
\text { increase in the intracellular ROS production. These also affected the cell cycle for inhibiting the cell } \\
\text { replication. AgNPs shows anti-cancer activity against HeLa cell type. }\end{array}$ & $\begin{array}{l}\text { Phenols, } \quad \beta \text {-sitosterol, } \\
\text { caffeoylquinic acid, } \\
\text { quercetin, kaempferol. }\end{array}$ & [26] \\
\hline $\begin{array}{l}\text { 9. Moringa } \\
\text { oleifera } \text { stem }\end{array}$ & Anti-bacterial activity & a) & $\begin{array}{l}\text { Different extracts of Moringa oleifera such as methanol, chloroform, ethyl acetate and aqueous were evaluated } \\
\text { for its activity by paper disc diffusion method. All extracts irrespective of its type inhibited the growth of test } \\
\text { pathogens to different degrees. In comparison between these extracts ethyl acetate extract have shown the } \\
\text { maximum activity and then in decreasing order by chloroform, methanol and aqueous extracts. }\end{array}$ & $\begin{array}{l}\text { Alkaloids, flavonoids, } \\
\text { tannins and terpenoids. }\end{array}$ & [27] \\
\hline $\begin{array}{l}\text { 10. Moringa } \\
\text { oleifera stem }\end{array}$ & Anti-ulcer activity & a) & $\begin{array}{l}\text { Ethanol extract of root-bark of Moringa oleifera posses anti-ulcer, antisecretory and cytoprotective activity. } \\
\text { Moringa oleifera has the potential to cure gastric ulcers and gastric mucosal lesions. It also decreases the } \\
\text { acidity and increases the pH of gastric juice. }\end{array}$ & $\begin{array}{ll}\text { Alkaloids, } & \\
\text { carbohydrates, } & \text { proteins, } \\
\text { tannins, } & \text { phenols, } \\
\text { steroids, } & \text { saponins, } \\
\text { triterpinoids. } & \\
\end{array}$ & [28] \\
\hline $\begin{array}{l}\text { 11. Moringa } \\
\text { oleifera stem }\end{array}$ & Antioxidant activity & a) & $\begin{array}{l}\text { Crude petroleum ether, chloroform, methanolic extracts of stem of Moringa oleifera were tested for their } \\
\text { antioxidant activity using DPPH radical scavenging assay method. }\end{array}$ & $\begin{array}{lr}\text { Tannins, } & \text { flavonoids, } \\
\text { steroids, } \quad \text { alkaloids, } \\
\text { triterpenoids, } \quad \text { sterols, } \\
\text { procyanidins, }\end{array}$ & [29], [30] \\
\hline $\begin{array}{l}\text { 12. Moringa } \\
\text { oleifera } \text { stem }\end{array}$ & Anti-arthritic activity & a) & $\begin{array}{l}\text { Methanol extract of stem of Moringa oleifera was evaluated for anti-arthritic activity by acute and chronic } \\
\text { models of inflammation. Different doses of Moringa significantly inhibit the inflammation and also show anti- } \\
\text { proliferative activities. }\end{array}$ & $\begin{array}{l}\text { Glycosides, saponins, } \\
\text { tannins, fats and oils, } \\
\text { steroids, triterpenoids, }\end{array}$ & [31] \\
\hline
\end{tabular}




\begin{tabular}{|c|c|c|c|c|c|}
\hline & & & & $\begin{array}{l}\text { alkaloids, proteins, } \\
\text { carbohydrates, } \\
\text { anthraquinones. }\end{array}$ & \\
\hline $\begin{array}{l}\text { 13.Moringa } \\
\text { oleifera } \\
\text { flower }\end{array}$ & Antioxidant activity & a) & $\begin{array}{l}\text { Alcohol extract of dried flowers of Moringa oleifera was obtained by cold maceration method. Antioxidant } \\
\text { activity of extract was evaluated by DPPH radical scavenging, showed potential radical scavenging activity. } \\
\text { Ethanol and saline extract of Moringa flowers were evaluated for antioxidant activity. The antioxidant activity } \\
\text { was stronger in ethanol extract than saline extract. }\end{array}$ & 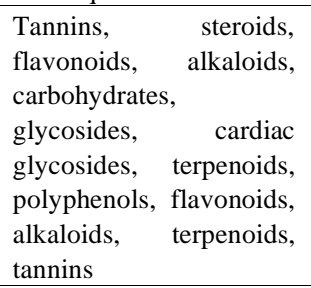 & $\begin{array}{l}{[32]} \\
{[33]}\end{array}$ \\
\hline $\begin{array}{l}\text { 14. Moringa } \\
\text { oleifera flower }\end{array}$ & SCAR Marker & a) & $\begin{array}{l}\text { Methanol extract of Moringa oleifera flowers was used to develop SCAR marker for authentification and DNA } \\
\text { based identification. }\end{array}$ & $\begin{array}{lr}\text { Phenolic, } & \text { flavonoid, } \\
\text { alkaloid, } & \text { terpenoids, } \\
\text { tannins, } & \text { steroids, } \\
\text { glycosides, } & \text { and } \\
\text { anthraquinone. } & \\
\end{array}$ & [34] \\
\hline $\begin{array}{l}\text { 15. Moringa } \\
\text { oleifera fruit }\end{array}$ & Anti-diabetic activity & a) & $\begin{array}{l}\text { Methanol extract of Moringa oleifera pods was evaluated for its anti-diabetic activity. It showed that extract } \\
\text { protects } \beta \text {-cells against ROS-mediated damage by enhancing cellular antioxidant defenses and } \\
\text { minimizing hyperglycemia in STZ-induced diabetes }\end{array}$ & $\begin{array}{l}\text { Quercetin, kaempferol, } \\
\text { flavanoids, methyl- } \\
\text { p-hydroxybenzoate, } \\
\text { beta- sitosterol }\end{array}$ & [35] \\
\hline $\begin{array}{l}\text { 16. Moringa } \\
\text { oleifera fruit }\end{array}$ & $\begin{array}{l}\text { Antimicrobial and } \\
\text { Anti-fungal activities }\end{array}$ & a) & $\begin{array}{l}\text { Methanol extract of Moringa oleifera fruit showed that it exhibits anti microbial activity against the tested } \\
\text { microorganisms at different given concentrations. The fruit extract has shown mild to moderate anti-fungal } \\
\text { activity also. The extract has shown a broad spectrum of antibacterial activity. }\end{array}$ & $\begin{array}{l}\text { Beta-sitosterol, } \\
\text { carotenoids, flavonoids }\end{array}$ & [36] \\
\hline $\begin{array}{l}\text { 17. Moringa } \\
\text { oleifera fruit }\end{array}$ & Antioxidant activity & a) & $\begin{array}{l}\text { Methanol extract of Moringa oleifera pods evaluated for its antioxidant activity concluded that it has promising } \\
\text { antioxidant effects. } \\
\text { Ethanolic extract of Moringa oleifera pods was evaluated for its antioxidant activity by both in vitro and in vivo } \\
\text { analysis such as DPPH radical scavenging, FRAP, and total antioxidant activity. }\end{array}$ & $\begin{array}{l}\text { Polyphenols, } \\
\text { tannins, anthocyanin, } \\
\text { glycosides, } \\
\text { thiocarbamates }\end{array}$ & [35] [37] \\
\hline $\begin{array}{l}\text { 18. Moringa } \\
\text { oleifera roots }\end{array}$ & Antiulcer activity & a) & $\begin{array}{l}\text { Ethanol extract of root-bark of Moringa oleifera posses anti-ulcer, anti-secretory and cytoprotective activity. } \\
\text { Moringa oleifera has the potential to cure gastric ulcers and gastric mucosal lesions. It also decreases the } \\
\text { acidity and increases the } \mathrm{pH} \text { of gastric juice. }\end{array}$ & $\begin{array}{l}\text { Alkaloids, } \\
\text { carbohydrates, proteins, } \\
\text { tannins, phenols, steroids } \\
\text { Saponins, triterpinoids. }\end{array}$ & [28] \\
\hline $\begin{array}{l}\text { 19. Moringa } \\
\text { oleifera roots }\end{array}$ & $\begin{array}{l}\text { Anti-inflammatory } \\
\text { activity }\end{array}$ & a) & $\begin{array}{l}\text { Methanol extract of root of Moringa oleifera was screened for its anti-inflammatory properties by using } \\
\text { carrageen induced paw oedema and 6-day air pouch inflammation. The results obtained from the study } \\
\text { concludes that the extract exhibits anti-inflammatory properties and may be useful in the treatment for both } \\
\text { acute and chronic inflammation. }\end{array}$ & $\begin{array}{l}\text { Benzyl glucosinolate, } \\
\text { quercetin, kaempferol, } \\
\text { flavonoids, alkaloids, } \\
\text { saponins, saccharides, } \\
\text { glucosinolates, tannins, } \\
\text { phenolic acids and nitrile } \\
\text { glycosides. }\end{array}$ & [38], [39] \\
\hline $\begin{array}{l}\text { 20. Moringa } \\
\text { oleifera } \text { roots }\end{array}$ & Antimicrobial activity & & $\begin{array}{l}\text { Different extracts of Moringa oleifera root was evaluated for its antimicrobial activity against Escherichia coli, } \\
\text { Staphylococcus aureus, Pseudomonas aeruginosa, Proteus mirabilis, Penicillium sp., Mucor sp., Aspergillus } \\
\text { niger and Candida albicans by disc diffusion method. Ethyl acetate extract showed broad spectrum of } \\
\text { antibacterial activity than other extracts. Aqueous extract showed maximum activity against Penicillium } \\
\text { species. }\end{array}$ & $\begin{array}{l}\text { Alkaloids, flavonoids, } \\
\text { saponins, terpenoids, } \\
\text { steroids, tannins, } \\
\text { cardioglycosides, } \\
\text { aminoacids and proteins }\end{array}$ & [40] \\
\hline
\end{tabular}




\begin{tabular}{|c|c|c|c|c|c|}
\hline $\begin{array}{l}\text { 21. Moringa } \\
\text { oleifera roots }\end{array}$ & Anti-mutagenic activity & a) & $\begin{array}{l}\text { Aqueous extract of Moringa root was prepared by heat treatment. Mutagenicity was assayed by the standard } \\
\text { Ames test. The result from this concluded that various phyto-chemicals, such as tannins, flavonoids, phenolics } \\
\text { etc present in Moringa contribute in its anti-mutagenic activity. }\end{array}$ & $\begin{array}{lr}\text { Tannins, } & \text { saponin, } \\
\text { flavonoids, } & \text { steroids, } \\
\text { terpenoids, } & \\
\text { glycoside } & \text { zeatin, } \\
\text { quercetin, b-sitosterol, } \\
\text { caffeoylquinic acid and } \\
\text { kaempferol. }\end{array}$ & [41] \\
\hline $\begin{array}{l}\text { 22. Moringa } \\
\text { oleifera roots }\end{array}$ & CNS activities & a) & $\begin{array}{l}\text { Methanol extract of Moringa root was prepared by soxhelet method. Different activities were performed such } \\
\text { as analgesic activity, effect on sleeping time, anticonvulsive activity and behavioral effect. From this study, it } \\
\text { was concluded that the extract exhibits CNS depressant action in dose dependent manner. }\end{array}$ & $\begin{array}{l}\text { Alkaloids, quercetin, } \\
\text { kaempferol, } \\
\text { glucosinolates, fatty } \\
\text { acids, isothiocyanates }\end{array}$ & [42] \\
\hline $\begin{array}{l}\text { 23. Moringa } \\
\text { oleifera roots }\end{array}$ & Anti-urolithiatic activity & a) & $\begin{array}{l}\text { Aqueous and alcoholic extracts were prepared from Moringa root by maceration method. The aqueous and } \\
\text { alcoholic extracts of Moringa root causes } 29 \text { ieresis and dissolves the preformed stones and prevents new stone } \\
\text { formation in urinary system. }\end{array}$ & $\begin{array}{l}\text { Alkaloids, } \\
\text { pterygospermin, 2-nitrile } \\
\text { glycosides, niaziminin, } \\
4-\left\{\left(4 \_-O \text {-acetyl-alpha-1- }\right.\right. \\
\text { rhamnosyloxy }) \text { benzyl }\} \\
\text { isothiocyanate }\end{array}$ & [43] \\
\hline $\begin{array}{l}\text { 24. Moringa } \\
\text { oleifera seeds }\end{array}$ & Anti-diabetic activity & a) & $\begin{array}{l}\text { Moringa seed powder was investigated for its anti-diabetic activity in STZ-induced diabetic rats. The result of } \\
\text { the study concluded that its effects are dose dependent on diabetic rats. Higher doses of Moringa seed powder } \\
\text { have shown more anti-diabetic effect then lower doses due to the presence of more phytochemicals present in } \\
\text { the higher dose such as glucomoringin, phenols and flavonoids. }\end{array}$ & $\begin{array}{l}\text { Glucosinolates, } \\
\text { glucomoringin, } \\
\text { quercetin, phenols, } \\
\text { kaempferol and } \\
\text { chlorogenic acid } \\
\end{array}$ & [44] \\
\hline $\begin{array}{l}\text { 25. Moringa } \\
\text { oleifera seeds }\end{array}$ & Anti-fungal activity & a) & $\begin{array}{l}\text { Ethanol extract of Moringa seed showed anti fungal activity against Trichophyton rubrum, Trichophyton } \\
\text { mentagrophytes, Epidermophyton Xoccosum, and Microsporum canis. GC-MS analysis was done for the } \\
\text { evaluation of chemical composition of the extract. }\end{array}$ & $\begin{array}{l}\text { Oleic acid, palmitoleic } \\
\text { acid, stearic acid, } \\
\text { arachidic acid. }\end{array}$ & [45] \\
\hline $\begin{array}{l}\text { 26. Moringa } \\
\text { oleifera seeds }\end{array}$ & Antioxidant activity & & $\begin{array}{l}\text { Moringa seed kernel was extracted by methanol, acetone and water individually. From the result of the study it } \\
\text { was concluded that among all the extracts, water extract of Moringa seed kernel possessed potent antioxidant } \\
\text { activity. }\end{array}$ & $\begin{array}{l}\text { 4(alphal- } \\
\text { rhamnosyloxy) benzyl } \\
\text { isothiocyanate, } \\
\text { 4-hydroxyphenyl-acetam } \\
\text { ide, 9-octadecenoic } \\
\text { acid, } \\
O \text {-ethyl-4-( } \alpha \text {-l-rhamnosy } \\
\text { loxy) benzyl carbamate, } \\
\text { niazimicin, } \\
\text { niazirin. }\end{array}$ & [46] \\
\hline
\end{tabular}




\section{Toxicological Profile}

Toxicity profile has been studied for various parts of Moringa oleifera such as its leaves, roots and seeds. Some of them are listed below;

- Acute toxicity of Moringa oleifera dried leaf powder at $2000 \mathrm{mg} / \mathrm{kg}$ was studied on Sprague Dawley rodents according to OECD Guidelines 423. Animals watched for every hour, in its underlying period for 14 days and no unfriendly responses were seen, for an additional 7 days. From the examination it was demonstrated that oral administration of dried Moringa oleifera leaves powder upto $2000 \mathrm{mg} / \mathrm{kg}$ indicated no adverse impacts and its LD50 saw as more than $2000 \mathrm{mg} / \mathrm{kg}$ [47].

- Acute and chronic poisonous quality of the aqueous extract of Moringa oleifera leaves were contemplated by oral administration. Acute toxicity was induced by directing $10 \mathrm{~g} / \mathrm{kg}$. This portion gave no indications of antagonistic responses in mice. In chronic lethality study, eighty Wistar rats were isolated into four groups having 10 creatures in each gathering per sex. Group 1 was the control group and Group 2 to 4 were given $10,100,1000 \mathrm{mg} / \mathrm{kg} /$ day for a half year. The outcomes from chronic toxicity examination uncovered that on various portions given to various groups, no change was seen by and large wellbeing status of rodents [48].

- Ethanol concentrates of Moringa oleifera leaves were surveyed for acute toxicity studies. Two groups, each with 6 creatures were made, for both, rats and rabbits. The concentrate was infused by intraperitoneal route with $150 \mathrm{mg} / \mathrm{ml}$ in like clockwork till death of the creatures happened. The outcome uncovered that LD50 for rats was $6616.67 \mathrm{mg} / \mathrm{kg}$ body weight and for rabbits was $26043.67 \mathrm{mg} / \mathrm{kg}$ body weight [49].

- Sub-chronic toxicity study of Moringa oleifera leaf powder was assessed. For the examination, 1000 $\mathrm{mg} / \mathrm{kg}$ per oral every day was administered to mice for ninety days. In the investigation, no change was seen in clinical or net pathology over a drawn out incessant presentation of 90 days[50]

- Acute toxicity study of Moringa oleifera roots was dictated by giving a solitary oral portion to mice and watched for $24 \mathrm{~h}$. The LD50 of ethanol extricate was $17 \mathrm{~g} / \mathrm{kg}$ and that of watery concentrate was $15 \mathrm{~g} / \mathrm{kg}$. Both the concentrates are generally non-poisonous when given in a solitary portion [51].

- Toxicity profile of Moringa oleifera leaves and seeds were concentrated to watch the consequences for fundamental organs of Wistar rodents. Methanol concentrates of leaves and seeds were arranged and controlled orally in portions 100, 200, 400 and 1000 $\mathrm{mg} / \mathrm{kg}$ to 8 gatherings containing 5 rodents for each gathering for 28 days. Histopathological changes were seen in the heart, liver, lungs, spleen and kidneys of rodents treated with the concentrates at all dosages tried. Some other physical changes like fomentation, disarray and confusion were seen at the most elevated portion tried $(1000 \mathrm{mg} / \mathrm{kg})$ of the seed extricate [52].

\section{Therapeutic \& Industrial Significance}

Moringa oleifera has demonstrated its flexibility in different fields other than its therapeutic properties. Different reports are there to demonstrate its multipurpose uses of a large portion of the parts of plant for example, nourishment, pharmaceutical, and restorative, mechanical, horticultural. In an investigation, it was demonstrated that, there is an enormous degree in charge of contamination by planting Moringa oleifera trees on huge scales, as it stores a lot of carbon in them. Moringa oleifera tree assumes a significant job in environmental change alleviation [53]. Moringa oleifera have natural coagulant activity [54]. Research facility ponders have indicated that Moringa oleifera seed have successful coagulative properties and are non-dangerous in nature. It has been utilized as essential coagulant for water treatment as water filtration and expel upto $99 \%$ of microscopic organisms [55].

In another examination, Moringa oleifera has been utilized as fish preservative. The protein protease inhibitor got from Moringa oleifera has extension to turn into a perfect up-and-comer in safeguarding of fish against proteolysis [56]. It is additionally a significant part in culinary world. Other than nourishment additive it is likewise used to season different Indian curries, particularly in South India [4]. Moringa oleifera seeds could be utilized as a more affordable biosorbent for the evacuation of cadmium $(\mathrm{Cd})$ from fluid media. Fluid arrangement of Moringa oleifera contains heterogeneous complex blend with different functional groups. These amino acids establish physiologically dynamic group of binding agents, which works even at low fixation, in view of its capacity to associate with metal particles to expand the sorption of metal particles [57]. In different investigations it has been demonstrated that leaves seeds and blossoms of Moringa oleifera have ovicidal, larvicidal and insecticidal potential against the vectors of the species Anopheles stephensi and Aedes aegypti [58].

Moringa oleifera has demonstrated its potential in biogas creation. The seed cake powder got from hexane concentrate of Moringa stenopetala was broke down for biogas generation. Biogas plant could add to wipe out waste issues from businesses having natural waste. This biogas plant can give modest vitality to that industry, or can likewise give this vitality to deal for e.g., vehicles. Not just this, biogas plant delivers a condensation that can be magnificent compost, and which can be sold for example to ranchers. Supplanting substance composts with this bio manure will add significant minerals to the dirt and in this 
way add to build the richness of cultivated land. In restorative industry likewise, Moringa is exceptionally esteemed. It is best for back rub and fragrance based treatment applications. Its oil contains hostile to maturing properties which humors it in different scopes of items for example against maturing creams, fragrance based treatment oils, knead oil, scents and antiperspirants [59]. The recuperating properties of Moringa oil were recorded by old societies. Moringa oil has uncommon oxidative strength which may clarify why the Egyptians put containers of Moringa oil in their tombs. Moringa oil is high in oleic corrosive and spreads effectively on the skin [60].

\section{Conclusions}

The multi advantages of Moringa oleifera plant made it "Marvel plant" of nature. It's the most modest plant with conveying potential in each perspective industry, beautifying agents, wholesome advantages, and agribusiness; and so on the vast majority of the parts of plant like seeds, blooms, leaves, and roots are utilized for treatment of different infections. Research reports that ethanolic, aqueous and methanolic extracts are broadly utilized for examination, identification, and estimation reason. Moringa oleifera plant is reasonable and modest to develop and grow in Asia. Moringa oleifera could be developed in contamination inclined and to control the climatic changes. In future the dynamic constituents can be disengaged and detailed into reasonable dose structure and conveyance framework and in-vivo examines dependent on creature models should be possible for better impact. Because of its different pharmacological uses this plant holds various promising moieties for separation of constituents and future clinical examinations.

\section{Acknowledgements}

The authors are very grateful to Prof. (Dr.) Soumana Datta, Department of Botany, University of Rajasthan, for providing detailed information and suggestions about the present work done on Moringa oleifera.

\section{REFERENCES}

[1] Paikra BK, Kumar H, Dhongade J, Gidwani B. Phytochemistry and pharmacology of Moringa oleifera Lam. J. Pharmacopuncture. 2017; 20(3): 194-200.

[2] Razis AF, Ibrahim A, Kntayya SB, Health benefits of Moringa oleifera. Asian Pac J. Cancer Prev. 2014; 15 (20): 8571-8576.
[3] Matic I, Guidi A, Kenzo M, Mattei M, Galgani A, Investigation of medicinal plants traditionally used as dietary supplements; A review on Moringa oleifera. J. Public Health in Africa, 2018; 9: 841.

[4] Paliwal R, Sharma V, Pracheta. A Review on Horse Radish Tree (Moringa oleifera): A multipurpose tree with high economic and commercial importance. Asian J. Biotech. 2011; 3: 317-328.

[5] Melesse A, Bulang $\mathrm{M}$ and Kluth $\mathrm{H}$, Evaluating the nutritive values and in vitro degradability characteristics of leaves, seeds and seedpods from Moringa stenopetala, J. Science of Food and Agriculture, 2009; 89: 281-287.

[6] Saini RK, Sivanesan I, Keum YS. Phytochemicals of Moringa oleifera: A review of their nutritional, therapeutic and industrial significance. Biotech. 2016; 6 (203): 1-14.

[7] Aja PM, Nwachukwu N, Ibiam UA, Igwenyi IO, Offor CE, Orji UO. Chemical constituents of Moringa oleifera leaves and seeds from Abakaliki, Nigeria. American J. Phytomed. and Clin. Therap. 2014; 2(3), 310-321.

[8] Soliman G. Anti-diabetic activity of dried Moringa oleifera leaves in normal and streptozotocin (stz)-induced diabetic male rats. Indian J. App. Res. 2013; 3(9), 18-23.

[9] Bamagous G, Ghamdi S, Ibrahim A, Mahfoz A, Mohamed A, Alsugoor M, Shammah A, Arulselvan P, Rengarajan T. Anti-diabetic and antioxidant activity of ethyl acetate extract fraction of Moringa oleifera leaves in streptozotocin-induced diabetes rats via inhibition of inflammatory mediators. Asian Pacific J. Trop. Biomed. 2018; 8(6): 320-327.

[10] Edoga CO, Njoku OO, Amadi EN, Okeke JJ. Blood sugar lowering effect of Moringa oleifera Lam in albino rats. International J. Science and Tech. 2013; 3(1): 88-90.

[11] Villarruel-López A, López-de la Mora DA, Vázquez-Paulino OD, Puebla-Mora AG, Torres-Vitela R, Guerrero-Quiroz LA. Effect of Moringa oleifera consumption on diabetic rats. BMC Compl. and Alternative Med. 2018; 18(127): 1-10.

[12] Jaiswal D, Rai P, Kumar A, Mehta S, Watal G. Effect of Moringa oleifera Lam. leaves aqueous extract therapy on hyperglycemic rats. J. Ethnopharmacol. 2009; 123: 392-396.

[13] Onyagbodor OA, Aprioku JA. Moringa oleifera leaf extract inhibits diabetogenic effect of alloxan in rats. IOSR J. Pharmacy. 2017; 7(10): 7-12.

[14] Azevedo I. M, Filho I. A, Teixeira M. M, Daniela M, Medeiros A. C, Wound healing of diabetic rats treated with Moringa oleifera extract, Acta Cir Bras. 2018; 33(9):799-805.

[15] González T, Martínez-G, Flores C, Luna N, Contreras M, Magdaleno M. Behavioral and electroencephalographic evaluation of the anticonvulsive activity of Moringa oleifera leaf non-polar extracts and one metabolite in PTZ-induced seizures. Phytomedicine. 2018; 39: 1-9.

[16] Kaur G, Invally M, Sanzagiri R, Buttar HS. Evaluation of the antidepressant activity of Moringa oleifera alone and in combination with fluoxetine. J. Ayurveda \& Integrative Medicine. 2015; 6(4): $273-279$. 
[17] Bakre AG. Studies on neuropharmacological profile of ethanol extract of Moringa oleifera leaves in mice. J. Ethnopharmacol. 2013: $1-7$.

[18] Wright RJ, Lee KS, Hyacinth HI, Hibbert JM, Reid ME, Wheatley AO, Asemota HN. An investigation of the antioxidant capacity in extracts from Moringa oleifera plants grown in Jamaica. Plants (Basel). 2017; 6(4); E48.

[19] Sreelatha S, Padma PR. Antioxidant activity and total phenolic content of Moringa oleifera leaves in two stages of maturity. Plant Foods Hum Nutr. 2009; 64:303-311.

[20] Abdalla E, Hadary El, Ramadan MF. Antioxidant traits and protective impact of Moringa oleifera leaf extract against diclofenac sodium - induced liver toxicity in rats. J. Food Biochem. 2019; 43: 1-9.

[21] Charoensin S. Antioxidant and anticancer activities of Moringa oleifera leaves. J. Medical Plant Research. 2014; 8(7): 318-325.

[22] Rao KNV, Gopalakrishnan V, Loganathan V, Nathan SS. Anti-inflammatory activity of Moringa oleifera.Ancient Science of Life. 1999; 18 (3): 195-198.

[23] Martínez-González CL, Martínez L, et al. Moringa oleifera, a species with potential, analgesic and anti-inflammatory activities, Biomed. \& Pharmaco. 2017; 87: 482-488.

[24] Adedapo AA, Falayi OO, Oyagbemi AA. Evaluation of the analgesic, anti-inflammatory, anti-oxidant, phytochemical and toxicological properties of the methanolic leaf extract of commercially processed Moringa oleifera in some laboratory animals. J Basic Clin Physiol Pharmacol. 2015: 2-9.

[25] Rajanandh MG, Satishkumar MN, Elango K, Suresh B. Moringa oleifera Lam. An herbal medicine for hyperlipidemia: A preclinical report. Asian Pac J of Trop. Disease. 2012; 2:S 790-S795.

[26] Vasanth K, Ilango K, Mohan R, Agrawal A, Dubey GP. Anticancer activity of Moringa oleifera mediated silver nanoparticles on human cervical carcinoma cells by apoptsis induction. Colloids Surf B Biointerfaces. 2014; 117:354-359.

[27] Zaffer M, Ahmad S, Sharma R, Mahajan S, Gupta A, Agnihotri RK. Antibacterial activity of bark extracts of Moringa oleifera Lam. against some selected bacteria. Pak. J. Pharm. Science. 2014; 27(6); 1857-1862.

[28] Choudhary MK. Bodakhe SH, Gupta SK. Assessment of the antiulcer potential of Moringa oleifera root-bark extract in rats. J. Acupuncture and meridian studies. 2013; 6(4): 214-220.

[29] Kumbhare MR, Guleha V, Sivakumar T. Estimation of total phenolic content, cytotoxicity and in-vitro antioxidant activity of stem bark of Moringa oleifera. Asian Pac J Trop Disease. 2012; 2(2): 144-150.

[30] Atawodi SE, Atawodi JC, Idakwo GA, Pfundstein B, Haubner R, Wurtele G. Evaluation of the polyphenol content and antioxidant properties of methanol extracts of the leaves, stem, and root barks of Moringa oleifera Lam. J Med Food. 2010; 13 (3): 710-716.

[31] Kumar V, Verma A, Ahmed D, Sachan NK, Anwar F, Mohd. M. Fostered Antiarthritic upshot of Moringa oleifera Lam. stem bark extract in diversely induced arthritis in wistar rats with plausible mechanism. IJPSR. 2013; 4(10): 3894-3901.

[32] Alhakmani F, Kumar S, Khan SL. Estimation of total phenolic content, in-vitro antioxidant and antiinflammatory activity of flowers of Moringa oleifera. Asian Pac J of Tropical Biomed. 2013; 3(8): 623-627.

[33] Santos AFS, Argolo AC, Paiva PM, Coelho LC. Antioxidant activity of Moringa oleifera tissue extracts. Phytotherapy research. 2012; 26(9):1366-1370.

[34] Gull I, Javed A, Aslam MS, Mushtaq R, Athar MA. Use of Moringa oleifera flower pod extract as natural preservative and development of SCAR Marker for ts DNA based identification. BioMed Research International. 2016: 1-12, Article ID 7584318.

[35] Gupta R, Mathur M, Bajaj VK, Katariya P, Yadav S, Kamal R, Gupta RS. Evaluation of antidiabetic and antioxidant activity of Moringa oleifera in experimental diabetes. $\mathbf{J}$ of Diabetes. 2012; 4: 164-171.

[36] Luqman S, Srivastava S, Kumar R, Maurya AK, Chanda D. Experimental assessment of Moringa oleifera leaf and fruit for its anti-stress, antioxidant and scavenging potential using in vivo and in vitro assays. Evid Based Complement Alternat Med. 2012;2012:519084.

[37] Sayeed MA, Hossain MS, Chowdhury ME, Haque M. In vitro antimicrobial activity of methanolic extract of Moringa oleifera Lam. Fruits. J Pharmacognosy and Phytochemistry. 2012; 1(4): 94-98.

[38] Ezeamuzie IC, Ambakederemo AW, Shode FO, Ekwebelem SC. Anti-inflammatory effects of Moringa oleifera root extract. International J of Pharmacognosy. 1996; 34(3): 207-212.

[39] Xu YB, Chen GL, Guo MQ. Antioxidant and anti-inflammatory activities of the crude extracts of Moringa oleifera from Kenya and their correlations with flavonoids. Antioxidants (Basel). 2019; 8: E296.

[40] Raj AJ, Gopalakrishnan VK, Yadav SA, Dorairaj S Antimicrobial activity of Moringa oleifera (Lam.) root extract. J of Pharmacy Research. 2011; 4(5): 1426-1427.

[41] Kumar S et al., Antimutagenic and antioxidant activity of Ficus benghalensis stem bark and Moringa oleifera root extract, International J of Chem and Ana Science, 2013; 4: $45-48$.

[42] Gupta M, Mazumder UK, Chakrabarti S. CNS activities of methanolic extract of Moringa oleifera root in mice. Fitoterapia. 1999; 70: 244-250.

[43] Kadil R et al., Effect of Moringa oleifera root-wood on ethylene glycol induced urolithiasis in rats, $\mathrm{J}$ of Ethnopharma, 2006; 105: 306-311.

[44] Abdulrahman L, Malki Al, Haddad A. The antidiabetic effect of low doses of Moringa oleifera Lam. seeds on streptozotocin induced diabetes and diabetic nephropathy in male rats. BioMed Research International. 2015, 1-13. Article ID 381040.

[45] Chuang PH, Lee CW, Chou JY, Murugan M, Shieh BJ, Chen HM. Anti-fungal activity of crude extracts and essential oil of Moringa oleifera Lam. Bioresource technology. 2007; 98 : 232-236. 
[46] Jahan IA, Hossain MH, Ahmed KS, Sultana Z, Biswas PK, Nada K. Antioxidant activity of Moringa oleifera seed extracts. Oriental Pharmacy and Experimental Medicine. 2018; 18; 299-307.

[47] Moodley I. Acute toxicity of Moringa oleifera leaf powder in rats. J of Medicinal Plants Studies. 2017; 5(5): 180-185.

[48] Chivapat S, Sincharoenpokai P, Saktiyasuthorn N, Shuapro A, Thongsrirak P, Sakpetch A, Rungsipipat A. Acute and chronic toxicity of Moringa oleifera Lin. leaves extracts. Thai J Vet Med. 2011; 41(4): 417-424.

[49] Osman HM, Shayoub ME, Babiker EM, Faiza AO, Munzir ME Ahmed, Bashier O, Elhassan AM. Assessment of acute toxicity and LD50 of Moringa oleifera ethanolic leave extract in albino rats and rabbits. J Med \& Bio Science Research. 2015; 1(4): 38-43.

[50] Moodley I. Evaluation of Sub Chronic Toxicity of Moringa oleifera Leaf Powder in Mice. JToxicology \& Pharmacology. 2018; 2(1): 19.

[51] Kasolo JN, Bimenya GS, Ojok L, Ogwal-okeng JW. Phytochemicals and acute toxicity of Moringa oleifera roots in mice. J Pharmacognosy and Phytotherapy. 2011; 3(3): $38-42$.

[52] Olayemi AT, Olanrewaju MJ, Oloruntoba AC. Toxicological evaluation of Moringa oleifera Lam seeds and leaves in wistar rats. Pharmacognosy Communications. 2016; 6(2):100-111.

[53] Daba M. Miracle Tree: A review on Multi-purposes of Moringa oleifera and its implication for climate change mitigation. J of Earth Science and Climatic Change. 2016; 7(8): $1-5$.

[54] Sutherland JP, Folkard GK, Mtawali MA, Grant WD. Moringa oleifera as a natural coagulant, 20th WEDC International Conference, Colombo, Sri Lanka, 1994; 297-299.

[55] Ndabigengesere A, Narasiah KS. Use of Moringa oleifera seeds as a primary coagulant in wastewater treatment. Environmental Technology. 1998; 9(8): 789-800.

[56] Bijina B, Chellappan S et al., Protease inhibitor from Moringa oleifera with potential for use as therapeutic drug and as seafood preservative. Saudi J of BioSciences. 2011; 18: 273-281.

[57] Anwar F, Latif S, Ashraf M, Gilani AH. Moringa oleifera: A food plant with multiple medicinal uses. Phytotherapy Research. 2007; 21: 17-25.

[58] Brilhante RSN et al., Research advances on the multiple use of Moringa oleifera: A sustainable alternative for socially neglected population. Asian Pac J of Trop Medicine. 2017;10(7):621-630.

[59] Mulugeta G, Fekadu A. Industrial and agricultural potentials of Moringa. J of Natural Sciences Research. 2014; 4(14): 57-63.

[60] Dubey DK, Dora J, Kumar A, Gulsan RK. A multipurpose tree- Moringa oleifera. International J of Pharm and Chem Sciences. 2013; 2(1): 415-423. 